\title{
CHAPTER NINE
}

\section{Western Greece (Magna Graecia)}

\author{
Peter Funke
}

\section{A 'Greater Greece' (Megale Hellas): Southern Italy and Sicily}

\section{The region}

While at the same time the Greeks were holding possession of both seaboards as far as the Strait of Messana, the Greeks and the barbarians carried on war with one another for a long time ... Later on ... the Greeks had taken away from the earlier inhabitants much of the interior country also, and indeed had increased in power to such an extent that they called this part of Italy, together with Sicily, Megale Hellas ['Greater Greece']. (Strabon 6.1.2)

In these few words the ancient geographer and historian Strabon (c. 64 BCE-25 CE) describes the close connections that existed between the Greek states in southern Italy and Sicily from their foundation in the colonization period to the Roman conquest. There was evidently, at least for Strabon, no doubt that Sicily too had to be subsumed under the term Megale Hellas or 'Greater Greece', commonly referred to in English as 'Magna Graecia', even though most other ancient authors seem to have restricted it to the southern part of the Italian peninsula (Polybios 2.39.1; Athenaios 523E). Accordingly, the term 'Greater Greece' signified the unity of a region which was not merely geographical in character, but was also a sphere of activity, and has retained this character down to our own day. The area south of a line stretching from the Gulf of Gaeta and the Gulf of Naples in the west to Monte Gargano and the Gulf of Manfredonia in the east forms, together with Sicily, a regional unit that in the course of history always preserved its own distinct - also political - character, and thus clearly differentiated itself from the central and northern regions of the Italian peninsula. What was called Megale Hellas in antiquity continued to be a region which European powers incessantly fought to control, 
down into modern times. Nor was it by chance that the spatial extent of Strabon's Megale Hellas corresponded - at least approximately - to that of the Royal Kingdom of 'Naples-Sicily' established by the Bourbons in 1735, and then at the Congress of Vienna in 1815 was revived under the name of the 'Kingdom of the Two Sicilies'. To this very day the so-called 'Mezzogiono' forms a world of its own and is separated from the rest of Italy by an imaginary boundary that was, however, concealed during the centuries of the Roman Empire and then again after the national unification of Italy in the nineteenth century, but was not actually obliterated, as Carlo Levi has impressively delineated in his novel Cristo si è fermato a Eboli.

The division of Italy into a northern region and into a southern one was at all times also determined by factors resulting from the way in which power politics played itself out: just as the Papal State of the Holy Roman Empire marked the boundary between the two from the Middle Ages until 1871, in like manner the Etruscans in the Archaic period prevented the Greeks from advancing further into the mineral-rich districts of the north of the peninsula. It was, however, in fact also geographical features that gave southern Italy and Sicily a distinct character, and thereby also created a specific sphere of action and a distinct environment (Kirsten 1975: 1-33). In the west, the southern foothills of the Apennines extend closer and closer to the coast of the Tyrrhenian Sea, and therefore act as an impediment to northbound traffic, since at the coast they fall precipitously to the sea, and in the interior they form an east-west barrier. At the same time, however, in this region, especially at river estuaries, many small coastal plains have formed, but which are accessible only from the sea, as they are cut off from the hinterland by mountain ranges. In other words, it is a landscape which is very similar to that along the coasts of the eastern Mediterranean, but found everywhere also in Sicily. By contrast, the east coast of southern Italy facing the Adriatic Sea is completely different. Here, southwards from Monte Gargano to the extreme south-east, there is a flat, narrow coastal plain which adjoins the arid Apulian plateau in the interior. Consequently, for the Greek colonists from the motherland who surged towards the west in the first half of the first millennium BCE, this coastal strip was much less inviting than the much more fertile coastline stretching around the boot of Italy from Tarentum in the east to Naples in the west, and around the whole of Sicily.

Moreover, it was only here that there were convenient harbours and favourably protected bays, but most of all fertile land for agriculture. In the fifth century the Greek poet Pindar refers to 'fertile Sicily' (Pindar Nemean Odes 1.15), and Strabon extols the fertility of the soil in Sicily: 'it is on the lips of all men, who declare that it is not a whit inferior to that of Italy. And in the matter of grain, honey, saffron and certain other products, one might call it even superior to Italy' (Strabon 6.2.7).

A glance at today's economic conditions in this area, often referred to as the 'poverty-stricken' region of Italy, makes it difficult to visualize the immense wealth which in the Archaic period drew wave after wave of Greeks to this 'New World'. It was not until the latter part of the Middle Ages and then above all in the early modern period with the wholesale exploitation of the natural resources, especially the clearing of large tracts of forests in the interior, that the agricultural foundations of the soil were continually undermined. In the Classical period, however, it was not least the growth in economic strength that prompted talk about 'Greater Hellas' (Athenaios 523E). Like pearls on a chain, the Greek colonial cities were strung along the coasts 
of southern Italy and Sicily. They formed a region whose economic prosperity could scarcely be rivalled, and which, because of its geographical location in the middle of the Mediterranean and at the point where Greek, Etruscan and Carthaginian-Phoenician spheres of influence intersected, was actually predestined to far-reaching trade connections. The early, very rapid spread of commerce based on coinage precisely in this region is a reflection of its economic potential. Innumerable, therefore, were the tales that circulated about the proverbial wealth of these cities. The philosopher Empedokles of Akragas described the life-style of his fellow-citizens as follows: 'The Akragantinians revel as if they must die tomorrow, and build as if they would live for ever' (Diogenes Laertios 8.63), and Diodoros, who was born in Agyrion on Sicily, called the city of Akragas: 'well-nigh the wealthiest of the Greek cities of that day' (Diodoros 13.90.4), and devoted a detailed discussion to its wealth (Diodoros 13.81-84.7; cf. also Athenaios 37B-D).

The geographical, economic and political realities turned southern Italy and Sicily into a world whose cohesion became well known throughout the whole of 'Greater Greece'. This name shows beyond doubt, however, that, despite the degree of independence that it asserted, this region had, at least in the eyes of the Greeks from the time of the colonization, become an integral part of the world of Greek states - i.e., of what Herodotos called to bellenikon (Hdt. 1.4.4). It is for this reason too that the envoys who came from the Greek motherland in 481 to the tyrant Gelon to enlist him as an ally against the Persian advance on Greece could appeal to this cohesion:

Your power is great; as lord of Sicily you possess no inconsiderable portion of the Greek world; we ask you, therefore, to help us, and to add your strength to ours in our struggle to maintain our country's liberty. Greece united will be strong and a match for the invader; but if in the body of our country there is but one limb... then there is reason to fear that all Greece may fall. (Hdt. 7.157.2)

Treasuries and votive offerings in Olympia, Delphi and many other large Panhellenic centres, as well as the victor lists of the Panhellenic games, offer abundant evidence of the integration of the 'Golden West' within the Greek world. How close these ties were is illustrated by a recently published bronze tablet bearing a sacred law from the Sicilian city of Selinous (SEG 48 630; Jameson et al. 1993). According to this inscription, the ekecheiria, an armistice proclaimed every four years for the duration of the Olympian games and binding on all Greek states, was in force even in the distant West already in the early fifth century, and, as in this instance in Selinous, quite unmistakably constituted a paramount fixture 'on the calendar' in the life of a city. Many other examples could be cited to show that there were close ties between the Greek motherland and the daughter-cities on the other side of the Ionian Sea. But these ties certainly did not produce any feelings of forced dependence. The poleis 'in the West' claimed for themselves the same political independence and freedom as the poleis on the Greek mainland; and although they as daughter-cities always remained fully conscious of the special bonds that existed between them and the mother-cities, and that their foundation legends were based on syngeneia, i.e., their common ancestry, political relations between them were just as much characterized by friendship and hostility as in all other Greek states. Indeed, it may have been precisely 
because of the special bonds - as in the case of neighbouring states - that in a lovehate relationship the pendulum between co-operation and confrontation often swung even further than was normal.

\section{The melting pot}

Neither for the Greeks who cast their gaze across the sea from the motherland to the West nor for those who had found a new homeland in southern Italy and Sicily was there the slightest doubt that this region of the Mediterranean was an integral part of the Greek oikoumene. And if today we speak of the 'Western Greeks', we too take this Greek perspective no less into consideration. Southern Italy and Sicily, however, had not merely become a new home for many Greeks. At the crossroads between East and West, already at an early date Sicily in particular became a jumping-off point also for the Phoenicians - initially from the Levant and then above all from Carthage. Later they actually established a permanent settlement on the island. As immediate neighbours of the Greek poleis they secured the north-west coast of Sicily as a sphere of influence and at the same time also as a link with their possessions on Sardinia and Corsica, and as a bridgehead for their commercial activities. The core of Carthaginian power, her epikrateia, rested on three bases on Sicily (Thuc. 6.2.6): in the extreme west there was the small offshore island of Motye, "the Phoenician beachhead from which to attack Sicily' (Diodoros 14.47.4) which, after its destruction by Dionysios I in 397, was replaced by strongly fortified Lilybaion; with possession of Panormos (modern Palermo) on the north coast the Carthaginians had control of 'the finest harbour in all Sicily' (Diodoros 22.10.4), whose coastal plain - it is still called 'conca d'oro' ('golden shell') - was known as a 'garden', thanks to its fertility and wealth in forests (Athenaios 542A); east of Panormos, Solous served as a Carthaginian military outpost.

While referring to the Greeks and the Carthaginians here, it is very easy to lose sight of the actual political and to some extent also of the ethnic diversity which existed in this region. By reason of their close ties with Carthage, however, the Punic colonies formed a relative homogeneity. By contrast, the situation in the Greek cities was different. Their inclusion in the Panhellenic community was only one side of the coin, as it were. To begin with, membership amongst the Greeks secured no more than a cultural identity, from which it was possible to gain political significance only seldom and only in very specific circumstances. It was at this Panhellenic level that in the West - apparently much more persistently than in most other parts of the Greek world - the awareness survived in the Classical period of belonging to one of the old Hellenic tribes, the Ionians or the Dorians. Alliances between individual cities were a distinct outgrowth of such tribal mentality. The rousing cry with which Hermokrates of Syracuse in the winter of $415 / 14$ appealed to the opposition between Ionians and Dorians in his attempt to mobilize the inhabitants of Kamarina against the Athenians (Thuc. 6.77; cf. Thuc. 4.61.2-3) shows that this tribal mentality, which was rooted in the traditions of the colonial period, was still alive and still found political resonance. Beyond that, however, there was a supra-polis identity amongst the western Greeks in any event in cases where convenient political alliances came about, as, e.g., amongst the Greek cities of southern Italy, who in the fifth and fourth centuries united against their indigenous neighbours. In this respect, however, there were narrow limits, for 
the same Hermokrates cited above employed the slogan 'Sicily for the Siceliots [Sikeliotai, viz. the Greek inhabitants in Sicily]' at the Peace Congress at Gela in 424 in his attempt to persuade the Sicilian Greeks to put aside their internal conflicts (Thuc. 4.58-64). But he failed to achieve a lasting success, as it was not long until the old rivalries amongst the poleis broke out afresh.

The polis of the day continued to be the actual centre-piece. In this respect too Magna Graecia exactly replicated the motherland, and to that extent the large number of its poleis structurally meshed precisely with the world of Greek states with the result that here the same areas of conflict prevailed as characterized interstate relations in other parts of the Mediterranean where Greeks were a factor. The divergent interests of many smaller and medium-sized states which at any given time sought to attain the highest possible degree of freedom and political independence opposed the efforts of larger poleis (they were competing no less amongst each other) to expand their own sphere of influence and establish a hegemony. The prosperity of the country fostered greed. Intense conflicts over territory, to which powerful cities like Siris and Sybaris fell victim already in the Archaic period, continued to be an enduring source of tension in the Classical period in inter-state relations. These conflicts were aggravated by reason of the fact that the tyrants at Syracuse in particular were determined to expand their sphere of influence beyond the confines of their polis and bring the largest territory possible under their control. In addition, there were the ongoing tensions from the struggle for involvement in the decision-making process within the individual poleis, which all too often culminated in violent civil wars. Although we can gain only a very fragmentary picture of events in the West from the ancient sources, it is impossible to avoid the impression that the conflicts amongst the poleis as well as within individual poleis in many instances exceeded what was otherwise regarded as normal, and went to great extremes - not least because of the imperialistic ambitions of the individual tyrants, who resorted to acts of brutality that can scarcely be exaggerated. The total destruction and obliteration of cities, the forcible resettlement of tens of thousands of inhabitants, but also the founding of new cities by newly constituted citizen groups, into which large numbers of non-Greeks, especially mercenaries, were integrated - these created an atmosphere of permanent instability and political insecurity.

Instability was further accentuated by the fact that the major 'sister states' in the motherland, like Athens, Sparta and Korinth, were all too ready to allow themselves to be drawn into the conflicts of their kindred poleis in the West in an effort to extend their own influence also over this region. The readiness of these 'foreign' powers, to which Carthage also belonged, to become involved only heightened political tension in the West. The picture which the Greek historian Thucydides (c. 460-400) paints, using the civil war on Kerkyra as an example of the cruel machinations in the political struggles in the Greek poleis (Thuc. 3.82-3), is often corroborated in the history of Magna Graecia in the Classical period. The outlines are often even clearer here since the potential for conflict was even greater in one fundamental point: the local population exerted a much greater influence here than in other parts of the Greek world. Alkibiades also drew attention to this factor in his speech in 415 while attempting to persuade the Athenians to embark on the Sicilian expedition: 'The Sicilian cities have swollen populations made out of all sorts of mixtures, and there are constant changes and rearrangements in the citizen bodies... Such a crowd as this is 
scarcely likely either to pay attention to one consistent policy or join together in concerted action' (Thuc. 6.17.2-4).

What Alkibiades in an indisputably negative undertone characterizes as 'motley rabbles' were the result of much more varied and much more complex interrelations which existed over many centuries from the beginning of colonization in southern Italy and Sicily, and which involved Greeks, Phoenicians and the native population.

It is very difficult to give an accurate description of the local population. The sources admittedly provide a plethora of names, but even ancient authors had already great difficulty in explaining descent, specific identity and the precise localities of individual peoples. This is not, however, surprising, since the emergence of ethnic groups does not necessarily follow any prescribed pattern and hard-and-fast rule, but is the result of a highly dynamic process and subject to constant change. This is particularly true of Magna Graecia in the fifth and fourth centuries. Despite the fact that our sources are extremely fragmentary, a synopsis of the historiographical, epigraphical and archaeological evidence (see below) makes it possible to conclude that during this period fundamental changes came about in the ethnic character of southern Italy and Sicily. These changes resulted in tension in relations between the local inhabitants - the Sikanoi/Sicanians and Sikeloi/Sicels - and those who came as settlers and conquerors - such as Greeks (Sikeliotai/Siceliots), Phoenicians but also Etruscans, and later the Romans. But this tension was by no means always of a hostile nature.

The conflicts arising from this new dynamic led to a process of confrontation and accommodation, which in part led to political reforms and changes in ethnic identity. Accordingly, in the course of the fifth century successive waves of Oscians left the arid mountain region of the Apennines and pushed their way into the fertile coastal region of Campania, and gradually took control of the cities there. In a counter-effect, this 'urbanization' led to the dissolution of the old tribal structures and also a merging into Mediterranean urban culture. Other tribes in the region of the Apennines joined together to form larger federations in order to reinforce their military strength, and in this way exert greater pressure on the Greek coastal cities in the south and west as well as on the 'Oscianized' cities of Campania - i.e., on their former kinsmen. In the higher ranges of the Apennines, Samnite tribes such as the Hippinians, Pentrians, Caudinians and Frentanians joined together to form a league in the fourth century. And in the south of the Italian peninsula the Oenotrians had merged with the earlier immigrants, the Lucanians, as early as the fifth century. Then, about 357 , the Bruttians, who themselves were part of the Lucanians, separated from these (Diodoros 16.15; Strabon 6.1.5; Justin 23.1.3-12) in order to found a separate alliance with a number of indigenous tribes - namely at the extreme south-west toe of Italy. On the east coast, in what is today Apulia and Calabria, the archaeological finds attest an increasing differentiation amongst the resident population, composed of immigrant tribes from across the Adriatic in Illyria - i.e., the Daunians, the Peucetians and the Messapians, who in the ancient sources are in part grouped together under the umbrella term of Iapyges (Hdt. 4.99.5; Strabon 6.3.2; differently, only Polybios 2.24.10). It is possible that here close contact with the Greek cities, particularly in the Gulf of Tarentum, led to politicization and a greater move towards independence on the part of these tribes. In Sicily it is possible to distinguish three chief indigenous groups: the Elymians in the extreme north-west, and the Sicanians and the Sicels in 
the west and central interior. The origin of the individual tribes was disputed even in antiquity (Thuc. 6.2), and still cannot be precisely clarified today, especially since the few, apparently Indo-European linguistic remains still elude a more precise identification, and - in part in contrast to earlier archaeological evidence - do not evince any particular connection with Italic dialects. As a result of the extremely close contacts with the Greeks and Phoenicians, all three tribes underwent an acculturation process, especially from the fifth century, whose impact on the political, social and cultural institutions of these indigenous tribes was probably more far-reaching than in comparable instances on the Italic mainland. While the Sicanians and the Sicels succeeded in apparently preserving their identity, the Elymians are no longer mentioned as an ethnic entity from the fifth century onwards. It seems that increasing urbanization in the wake of distinct Hellenization to a large degree undermined tribal cohesion, with the result that membership in a given city (among others, Segesta, Entella, Eryx) became the decisive factor for political identity, so that awareness of being Elymian faded into the background.

In other words, two quasi counter trends characterize the political restructuring of the indigenous peoples of southern Italy and Sicily. On the one hand, under external pressure individual tribes joined together in larger unions and formed strong tribal alliances. On the other, however, old tribal structures completely disappeared in favour of the formation of polis societies on the Greek model. The two developments do not differ that much, as the points of transition were fluid and in their manifold character the result of constant shifts between antagonism and accommodation. Nor does this in any way apply only to the process of political change described here, but on a much greater scale to the whole cultural realm. Those involved used the Greek script and in many instances also the Greek language. Along with the adoption of the idea of the Greek polis, its external manifestations were also taken over - such as architecture and art. As unmistakable as much that is Greek may appear, it is possible to observe a tendency to persist in old ways and to implement independent reforms. There was no firm line of demarcation between the Greek poleis and the Phoenician cities on the one hand, and, on the other, between the Greek poleis and the barbarian hinterland. Asheri has rightly talked about a 'dynamic model of cultural osmosis from the primary apoikiai on the coast to the indigenous interior, creating various intermediate forms of cultural life along the way' (Asheri 1988: 742-3).

The above sketch, although brief and punctuated by examples, should nonetheless suffice to demonstrate the tremendous dynamic energy which was released between foreigners and the indigenous population, and which led to lasting changes on all sides. For it was not only the indigenous peoples who were exposed to a strong transforming pressure. And it would be completely inappropriate to describe these interrelations exclusively as a product of Hellenization. The dominance of Greek influence is indeed beyond question. It was not, however, a one-sided give-andtake, but a manifold acculturation process, whose dimensions only gradually emerge - not least by reason of the fact that archaeological research has intensified. It was in the religious realm in particular that the melting pot of Magna Graecia produced a great wealth of syncretic results, in which Greek, Phoenician, Etruscan and indigenous elements blended in a complex manner with each other, and in doing so became a dynamic witness to accommodation with the other foreigners at any given time. 


\section{The distorted view: the sources}

The prime witnesses for the history of the fifth century, the historians Herodotos (c. 480-420) and Thucydides (c. 460-400), provide astonishingly little information on the history of the Greek West. In Herodotos this region actually assumes greater importance only within the context of the Greek preparations for the defence of Hellas against the Persians in 481, when the Greeks of the motherland sought to draw Syracuse, the new powerhouse in the West, into the anti-Persian coalition (Hdt. 7.153-67). And in his historical survey of the period between the Persian wars and the Peloponnesian War, Thucydides (Thuc. 1.89-118) completely omits any reference to southern Italy and Sicily. Not until the introduction to his account of Athens' Sicilian expedition in $\mathbf{4 1 5}$ does he give an extremely brief overview of the early history of the island, but without in any way taking developments in southern Italy into consideration. Thucydides offers an ethnographic excursus which is essentially restricted to a plain list of names and places connected with the history of the early settlement of the island by 'Hellenes and Barbarians'. Despite the great political importance of the Greek West in the Classical period, it received remarkably little mention in contemporary historiography in the motherland.

There was, however, no lack of efforts on the part of the 'Western Greeks' to correct this deficit in the history of the Greek states and to guarantee that their own history was given its proper place. A historiographical tradition actually began to develop in the West at a very early date, which was neither confined to the history of individual cities nor dwelt exclusively on ethnographic descriptions, but from the very outset took the history of the whole of Sicily within its scope, including also southern Italy ( FGrHist 3b pp. 479-82). This too is proof that this geographical region was at the same time also considered to be a separate political realm. Accordingly, already in the last third of the fifth century Antiochos of Syracuse (FGrHist 555) stepped forward as the immediate successor to Herodotos, and quite deliberately sought to fill the gaps left by him - namely by giving an account of the entire history of the Greek West from its mythical beginnings down to the Peace Congress at Gela in 424. Philistos of Syracuse (FGrHist 556) (c. 430-356/5), an imitator Thucydidi (Quintilian Institutio 10.1.74), denies his support to this 'Herodotos of the West' (FGrHist 3b p. 480). His Sikelika also started with the earliest beginnings, but the emphasis was, entirely in the tradition of Thucydides, on the history of his own time. As an intimate confidant of and advisor to Dionysios I and Dionysios II, he was seen as a 'philotyrannotatos', i.e., as an 'ultra pro-tyrant' (Plutarch Dion 36.3). Thanks to his great mastery of factual information, later writers used his History as an important source, but because of his otherwise extreme pro-tyrannical bias it was rejected. This was not the least reason why Philistos' History was soon forced into the background by Timaios of Tauromenion (FGrHist 566) (c. 350-260). He was the last and at the same time also probably the most influential author in the line of Greek historians whose works encompassed the history of the entire West.

Western Greece could therefore boast of a rich historiographical tradition, all the more since, in addition to the three authors cited above, there was a great number of other writers whose Histories are no longer extant in toto, and of whom in most instances we consequently know little other than their names and occasionally also the titles of their works. But the accounts of Antiochos, Philistos and Timaios became 
irretrievably lost in the period after the end of antiquity, and are today accessible only second-hand, in the works of later writers of the Roman period who used them as models for their own works. First and foremost in this respect are Diodoros, Dionysios of Halikarnassos and Strabon, but also the biographers Cornelius Nepos and Plutarch, and the learned man of letters Athenaios of Naukratis; moreover, the many quotations and references to be found in the geographical lexicon of Stephanos of Byzantion - these demonstrate that the works of historians of the Greek West were extant at least well into the sixth century. What have survived are rather paltry fragments and the accounts of later writers, and these afford only a dim reflection of the original works. This loss of historiographical knowledge cannot be made up for by relevant reports and references in contemporary poetry - these above all in the works of Pindar, Simonides, Bacchylides and also Aischylos - or by the philosophical writings of Plato, Xenophon or Aristotle. Granted that, e.g., the historical importance of Plato's Letters $(3,7,8$ and 13$)$ - quite apart from the question of their authenticity - is undisputed, they represent only a single instance, one portion of a much larger whole, which in its diversity is inaccessible. This applies to some extent also to the major problem of determining just what was the Pythagorean influence on the politics of the south Italian poleis in the first half of the fifth century - namely on the basis of the only extant late sources, i.e., of the Roman imperial period (Diogenes Laertios, Porphyrios and Iamblichos).

The extremely fragmentary state of the historiographical tradition causes our view of the history of the Greek West in the Classical period to be distorted. Consequently, every attempt to reconstruct it as a historical continuum must remain as patchy as the sources themselves, in which the Syracusan perspective all too often prevails, with the result that the history of the rest of Western Greece - especially southern Italy - fades into the background and is scarcely perceptible. Much of this is, however, offset by the increasing number of epigraphical finds and especially the extraordinary wealth of highly informative numismatic material. Moreover, in just the most recent decades excavations which have been carried out with great vigour have produced an unexpected harvest of historical information. Despite this, it is still impossible to close the gaps in the historiographical tradition, which in view of our knowledge of the lost wealth makes that loss all the more painful. Consequently, the discussion to follow here will perforce be selective and to a certain degree also random.

\section{From Tyranny to Democracy: The Fifth Century}

\section{Supremacy in the West}

It is customary to equate the end of the Persian wars in $480 / 79$ with the beginning of a new era in Greek history and to regard the defeat of Xerxes as the boundary between the Archaic and the Classical period. Even if such an approach perhaps overemphasizes the break which the Persian wars constitute, it will be impossible to deny that there were changes and transformations involved in these historical events which were already in antiquity regarded as fundamental turning-points. What appears to be entirely clear in respect of the motherland and the Greek East, however, is by no means as evident when it comes to the Western Greeks. Ancient historians nonetheless 
sought to integrate the events in the Greek West into this picture in as seamless a manner as possible - by, e.g., dating the Carthaginian attack on Sicily in 480 in the same year as Xerxes' offensive against Greece. Both military expeditions were allegedly the result of a co-ordinated strategy, with the object of conquering the whole Greek world by means of a gigantic pincer-movement (Diodoros 11.1.4-5; 20.1). With a view to linking both military events as closely as possible with each other, historians actually placed the Carthaginian defeat at Himera and the Persian defeat at Salamis on the same day (Hdt. 7.166; Thermopylai instead of Salamis, Diodoros 11.24.1); and Pindar compared the victory over the Carthaginians with the battles of Salamis and Plataiai (Pindar Pythian Odes 1.75-79; cf. also Diodoros 11.23.1).

Independent of the question of the authenticity of a Persian-Carthaginian joint strategy, still disputed today, it is necessary to interpret the events of 480 differently in respect of the Greek West as compared with the East. It is true that the outcome of the battle at Himera represented a decisive break in that for the next 70 years Carthage refrained from any military intervention, but it would be difficult to argue for a fundamental historical break. With his victory over the Carthaginians, Gelon was able to 'round off' his political ambitions, which had begun with his capture of Gela in 491. At the time, Gelon, a leading member of the noble family of the Deinomenids, had seized the inheritance of his predecessor Hippokrates after his death, and in the following years built up what Hippokrates had established on a firm foundation between 498 and 491 . Aided by a superbly organized bodyguard, an efficient mercenary force and a cavalry unit commanded by Gelon, Hippokrates had succeeded in expanding his rule far beyond Gela, indeed virtually over the entire south-east of Sicily. After conquering Katana, Naxos and for a time even Zankle (Messana), as well as many Sicel cities, he could only be prevented from seizing Syracuse because of the mediation of Korinth on behalf of her daughter-city.

Gelon then followed in the footsteps of Hippokrates with unflinching determination. And so in $\mathbf{4 8 5}$, when in Syracuse the protracted conflict between the leading oligarchic faction of the gamoroi and the democratic faction, allied with the killyrioi (the enslaved indigenous inhabitants), escalated into open hostilities, Gelon took advantage of the situation to invade, and conquered the city and reinstated the banished gamoroi, but without relinquishing power in Syracuse once he had seized it. Indeed, he now systematically turned Syracuse into his capital. At virtually the same time as Themistokles in Athens, Gelon in Syracuse too laid the foundations for the new supremacy in the West by building a harbour and fortifications, and by a comprehensive naval programme. The area encompassed by the city was greatly expanded and the size of the population significantly increased. From Gela alone, where Gelon installed his brother Hieron as tyrant, half the inhabitants were forced to resettle in Syracuse. Further mass deportations followed from previously conquered cities, from whose inhabitants the wealthy were granted Syracusan citizenship, while the members of the poorer classes were sold into slavery - since Gelon was persuaded that 'the masses are very disagreeable to live with' (Hdt. 7.156). In addition, Diodoros speaks of Gelon giving citizenship to 10,000 mercenaries (Diodoros 11.72.3).

The power which Gelon acquired by seizing Syracuse he expanded even further by means of adroit marriages. His marriage to Damarete, the daughter of Theron the tyrant of Akragas (he, in his turn, in a second marriage wed one of Gelon's nieces), 
sealed a political alliance whose strength could not be trumped, since Theron's power encompassed virtually the whole of northern Sicily. This constellation drove the other tyrants - most particularly Anaxilaos of Rhegion, who with Zankle/Messana had brought the straits between Sicily and southern Italy under his control, and Terillos, who had been driven out of Himera - into the arms of the Carthaginians, who were no longer willing to tolerate a further unification of Sicily under Syracusan initiative without taking action, and so proceeded to attack in 480 . The large-scale military advance, however, ended in a devastating defeat for the Carthaginians at Himera (Hdt. 7.165-7; Diodoros 11.20-6). Gelon emerged from the war in a strengthened position. The polygamous relations of his brother Hieron are an indication of how firmly his power was established. In a second marriage he took the daughter of Anaxilaos of Rhegion as his bride, and in a third marriage a niece of Theron of Akragas.

The marriage connection with the tyrant family in Rhegion is an indication that Hieron was already casting his eyes across the straits, to the mainland of Italy, in accordance with his expansionist foreign policy - i.e., after he took the place of his brother in 478 , who had just died. In $477 / 6$ he actively supported the inhabitants of Lokroi in a conflict with his father-in-law Anaxilaos of Rhegion (scholion to Pindar Pythian Odes 2.36), and at approximately the same time came to the aid of Sybaris in her fight against Kroton (Diodoros 11.48.4). Then in 474 Hieron responded to a call for help from Kyme against the Etruscans, and came away the triumphant victor in a naval battle in the Gulf of Naples. Pindar compared this victory with that of Gelon over the Carthaginians at Himera, and painted it as 'Hellas' deliverance from grievous slavery' (Pindar Pythian Odes 1.75). That Hieron's victory over the Etruscans paved the way for the rise of Rome is something which at the time probably could still not be foreseen. Hieron's successes in foreign policy expanded the sphere of influence of the Deinomenids deep within Italy. Through the friendly connection with Kyme and the temporary establishment of a military colony on the island of Pithekoussai (today Ischia) (Strabon 5.4.9) the southern sector of the Tyrrhenian Sea had gradually become a 'Syracusan lake' (Asheri 1992: 149).

Developments in the political realm were matched by flourishing activity in the cultural sphere, which continued to thrive even after the collapse of the tyrant regimes. The tyrants on Sicily summoned poets, artists and philosophers to their Courts, pursued a vigorous building programme and sought to raise their international profile by numerous victories at the Panhellenic games. Although their conduct may correspond at least in part to that of the tyrants in the motherland and in the Aegean in the Archaic period, their rule was characterized by fundamental differences and therefore took on a completely different style - one that in many respects approximated what was later to characterize the Hellenistic monarchies. This may explain the unquestionably anachronistic statement in Diodoros (it probably goes back to Timaios) that following his victory at Himera, Gelon, in a genuinely Hellenistic manner, was greeted as 'Benefactor, Saviour and King' (euergetes, soter, basileus) (Diodoros 11.26.6). Consequently, tyrannis in the West cannot be made to conform to the approach that prevailed in the nineteenth century, i.e., as divided into different phases along chronological lines: an 'older tyrannis' in the Archaic period, and a 'younger tyrannis' towards the end of the fifth century. In view of the great diversity in the instruments of government, a division into 'old' or 'young', 'atavistic' 
or 'modern' simply will not go down. The recruiting of bodyguards and mercenaries, the organization of spy networks, as well as political marriages and the promotion of art and culture were all part and parcel of the conduct of tyrants, although the polygamy of the Sicilian tyrants went far beyond the bounds of what was customary at the time, and already anticipated the practices of Hellenistic rulers.

The Sicilian tyrants, however, struck out into completely new paths by creating inclusive territorial states. Accordingly, the Deinomenids of Syracuse and the Emmenids of Akragas had succeeded in bringing large parts of Sicily under their direct rule in the first third of the fifth century. Even they, however, could not of course deprive the individual cities completely of their autonomy, but by pursuing a rigorous 'city policy', in which they did not shy away from radical intervention in the makeup of the citizenry or from the total destruction of cities, they did make sure that the cities they conquered remained docile. We have already mentioned Gelon's settlement policy in Syracuse. In 476 Hieron adopted a similar strategy in connection with the city of Katana, which may be cited as an example of the fate which overtook it: After initially transplanting her inhabitants as well as those of Naxos to Leontinoi, Hieron settled 10,000 new inhabitants - half from the Peloponnese and from Syracuse - and changed the name of the city from Katana to Aitna, and installed his son Deinomenes there as ruler. Hieron's new foundation, which Pindar celebrated in his first Pythian Ode and Aischylos in his play The Women of Aitna, however, lasted only a few years. After the fall of the Deinomenids, the original inhabitants returned to the city, which was once again called Katana, while Hieron's colonists settled in Inessa, which they renamed Aitna (Diodoros 11.49.1-2; 76.3; Strabon 6.2.3). In 403 the inhabitants of Katana once more became the victims of Syracusan policy, when Dionysios I conquered the city, had the inhabitants sold into slavery and settled Campanian mercenaries in their place. But after only a few years they too were transplanted to Aitna/Inessa.

The poleis and their inhabitants thus became a disposable mass, subject to the whims of the tyrant, whose goal continued to be that of securing his rule over the widest territory possible. Nonetheless, the tyrants were ever intent on not flaunting their personal power in public, but sought to integrate themselves into the discipline of the polis community and present themselves as part of the citizen body. Titles which the rulers assumed and by which they were addressed by the people, such as Diodoros ascribes to the Syracusans (see above), are not attested either in contemporary inscriptions or on coins. Instead, 'Gelon, son of Deinomenes, the Syracusan' dedicates to Apollo in Delphi a tripod as a thank offering for the victory at Himera (M\&L 28), and the bronze helmets which Hieron dedicated to Zeus at Olympia from the booty from the naval battle at Kyme were engraved as follows: 'Hieron, son of Deinomenes, and the Syracusans for Zeus from the Etruscan booty from Kyme' (M\&L 29; SEG $23253 ; 33$ 328). It is not until we reach Dionysios I that we have evidence for a title, in official decrees. In Athenian honours from 393 and 368 he is referred to as 'archon Sikelias' (R\&O 10;33; 34). But this title too, which no doubt had to have the endorsement of Dionysios I himself, reflects the attempt to paraphrase his political power in as neutral a language as possible. Employing the term archon, which could serve as a completely general designation for military or high civil office also in a polis, showed the intent of attempting to avoid any association with terms such as basileus (king), tyrannos or dymastes (Lewis 1994: 136-9). Thus tyrannis 
in Sicily, after its revival in the fourth century, took the same route for which the first tyrants had shown the way at the turn from the sixth to the fifth century. It therefore retained its entirely distinct character, which could not conceal its archaic roots, but at the same time already foreshadowed what was to become its essential expression in the Hellenistic period.

\section{The road to democracy - an interlude?}

The successors did not succeed in maintaining the inheritance of their predecessors. Within a single decade (471-461) the three major tyrant regimes in Syracuse, Akragas and Rhegion were eliminated, and the realms over which they had ruled collapsed like a house of cards. Upon succeeding his father, Thrasydaios of Akragas was able to maintain his rule for only one year $(472 / 1)$. After a vain attempt to challenge the supremacy of Hieron of Syracuse, the people of Akragas forced him to flee to Megara in Greece, where he was condemned to death and executed. In the following years the successors of Hieron and of Anaxilaos of Rhegion were both overthrown, after only a brief rule - i.e., after having themselves seized power from Hieron and Anaxilaos, respectively. As in a domino effect the tyrants were simply swept away. Their abrupt end clearly demonstrated that tyrannis was inextricably bound up with the personality of the individual holding power in the first instance, but also that tyrannis had simply become out of date and was shunted aside: the wealth and prosperity which increased significantly under the tyrants, and from which the rest of the population no doubt profited, strengthened the desire within the citizenry for greater participation in political decisions.

In addition, there was the pent-up opposition to the arbitrary manner in which the tyrants treated the cities. Mass deportations and the forced integration of tens of thousands, as well as the creation of new citizens including non-Greeks, led to serious tensions with the 'old citizens'. After the fall of the tyrants, these tensions culminated in prolonged conflicts bordering on civil war, until an agreement was reached which guaranteed the return to their original cities of those who had been deported and banished, and the settlement of all foreigners who had been granted citizen rights by the tyrants - mostly mercenaries - in Messana (Diodoros 11.72.2-73.3; 76.4-6). The coins of the period demonstrate the impressive revival of autonomy amongst the cities of Sicily, some of which - like Naxos and Kamarina - had to be completely rebuilt after having been destroyed by the tyrants (on the redistribution of the citizenry in Kamarina, see now the approximately 150 bronze tablets from the period, SEG 41 846 ; also $S E G 47$ 1431). But the restoration of the poleis apparently proceeded all the more smoothly because the political unrest evidently did not have any serious negative effect on prosperity (Diodoros 11.72.1). Moses Finley offers the following pertinent summary:

The end of tyranny saw no cessation in the outward signs of prosperity: in agriculture, in continuation of the tradition established by the tyrants of minting the finest coins, in the scale and quality of temple-building and of other public works. On the material side, it seemed as if Syracuse and Akragas had the necessary conditions to follow the path of Athens, where the tyranny had been overthrown in 508. (Finley 1979: 57) 
The same path was in fact followed. From everything we can deduce from the highly fragmentary information in the ancient sources, as a rule democratic factions came to power in the newly constituted poleis, and insisted on greater participation by the citizens in political decision-making. Many details - such as the introduction of petalismos in Syracuse (Diodoros 11.87.4), similar to ostracism in Athens - corresponded to those in democratic institutions known in other parts of the contemporary Greek world. To that extent the West was following the trends of the time.

Nonetheless, conditions in the West were fundamentally different. Indeed, the tyrants in the Greek West did not attempt to secure the support of the lower classes, as was the case elsewhere (Hdt. 7.156.2-3), but always remained closely aligned with the nobles. Although social changes came about from the tyrants having intervened in the very structure of the poleis, no consolidation of the lower classes took place. Consequently, after restoration of the poleis the aristocratic factions were able to re-establish themselves, under a democratic guise. Just how strong the influence was which they exerted is shown by the fact that in Syracuse the petalismos was, under pressure from the aristocrats, abolished not long after having been introduced (Diodoros 11.87.4). With this, certain social structures became consolidated, which thwarted any lasting political change and left little prospect for democratic development within the lower classes. Here we may also look for the reason why, after a promising beginning in overthrowing the tyranny, 'the endproduct proved to be weak and short-lived' (Finley 1979: 5), and why democracy remained an 'interlude' - if not indeed in the entire West, then at least in Sicily. (Finley 1979: 58-73).

No less of an interlude, albeit much shorter, was the attempt of the Sicel Douketios to exploit the confusion to establish a dominion of his own in the wake of the collapse of the tyrant regimes. Stemming from an eminent Sicel family (Diodoros 11.78.5), he sought to unite his fellow-Sicels into a kindred alliance - Diodoros refers to a synteleia or a koinon (Diodoros 11.88.6) - and thereby create a powerful counter-weight to the Greek poleis. Initially supported by Syracuse, Douketios was able to score substantial successes in the years after 461 , and in $453 / 2$, with the founding of the city of Palike in the immediate vicinity of a leading Sicel sanctuary, he established an urban centre for his newly created Sicel league (Diodoros 11.88.6-90.1). Even though Douketios may have played the Sicel card, it is scarcely possible to speak of a national Sicel revolt. Douketios' action doubtless bears the stamp of Greek tyrants, whom he used as his model. Indeed, 'Ducetius' models were Gelon and Hieron, not Kokalos or Hyblon of old' (Asheri 1992: 165). The founding of a Sicel league was therefore much more the result of an already highly advanced Hellenization of the Sicels than a conscious return to indigenous origins.

The constitutional changes in the Sicilian cities altered but little in respect of the struggles for supremacy. Thus, after the situation in domestic politics had become stabilized, Syracuse - along with Akragas - moved decisively against the growing power of Douketios. He was finally defeated in 450. After Douketios had been sent into exile in Korinth for several years, he returned to Sicily in $448 / 7$ in order to found the Greek-Sicel city of Kale Akte. It is uncertain to what degree Douketios was acting with the connivance of the Syracusans or was being used by them to further their own political ambitions. At all events, this affair led to conflict between Syracuse and 
Akragas, in which the other poleis also became involved. Douketios, who once more admittedly in vain - announced his claim to the leadership of the Sicels, became a player in the power politics of the rival cities until his death in 440 . In this drama Syracuse was able to re-establish her former hegemonic position until the end of the 430s. At the same time, there was a sharp increase in the conflicts amongst the various poleis: the call for outside help became increasingly more pronounced, and brought the major powers of mainland Greece upon the scene-above all Korinth and Athens, but eventually Sparta as well.

Although the Athenians had not participated in the colonization of the West, as had the Korinthians and the Spartans, they nonetheless had cast their gaze on southern Italy and Sicily ever since the time of the Persian wars. Themistokles is said to have named two of his daughters Sybaris and Italia (Plutarch Themistokles 32.2), and before the battle of Salamis Themistokles threatened to resettle all Athenians in Siris, which had been destroyed by her neighbours in the sixth century, and, as an Ionian city, 'has long been ours, and the oracles have foretold that Athenians must live there some day' (Hdt. 8.62.2).

In the middle of the fifth century Athens headed up a Panhellenic colonization venture, and carried out the founding of Thourioi at the site of Sybaris, which had been destroyed in 510 . And the treaties which Athens made with Rhegion, with Leontinoi $(M \& L 63,74)$ and eventually also with Segesta (M\&L 37 - possibly not until 418/17) and the Messapian leader Artas (Thuc. 7.33.4) go back to approximately the same period.

Within this configuration of events southern Italy was without fail also pulled into the undertow of the political conflicts which in the end engulfed the entire Greek world, i.e., the Peloponnesian War. Despite this, our sources provide extremely little information on the history of this region, which seems to have taken a very similar course to that of Sicily. In any event, it is possible to observe very similar developments in the constitutional history of the poleis in southern Italy, where, against the background of social tensions, the aristocratic-oligarchic regimes were also plunged into a crisis after the end of the sixth century. Here too demands for the extension of political participation by the citizenry had fostered the rise of tyrant regimes. According to later tradition, Pythagoras is said to have played a central role in the internal conflicts. He had emigrated from Samos c. 530 and settled in Kroton, where he founded a religious community, whose adherents attained great political influence in many poleis in the Greek West. 'Did not many of them act as guardians of the laws and govern Italic cities by proclaiming what in their view was best, and gave advice... It was evidently at this time that the best forms of government existed in Italy and Sicily' (Iamblichos Life of Pythagoras 129).

The rigorous and sectarian conduct of these aristocratically inclined men led to bitter internal conflicts, which culminated in a pogrom against the Pythagoreans about the middle of the fifth century:

When, in the district of Italy, then known as Greater Hellas, the club-houses of the Pythagoreans were burnt down, there ensued, as was natural, a general revolutionary movement, the leading citizens of each city having thus unexpectedly perished, and in all the Greek towns of the district murder, sedition and every kind of disturbance were rife. (Polybios 2.39.1-3; cf. also Iamblichos Life of Pythagoras 249) 
To all appearances, these political upheavals fostered the breakthrough of democratic forces, but without it becoming possible for us to discern more precisely the forms which these democracies assumed. Aristotle's reference to the democratic constitution of Taras (Tarentum) (Aristotle Politics 1320b9-16) at least suggests that it was a case of more or less moderate forms of democracy, which still afforded many opportunities for the aristocrats to exert their influence. But one had adjusted to the demands of the times and to political necessity. Beyond that, in the case of Tarentum events in foreign policy left the aristocrats no alternative after they had suffered a devastating defeat against the Messapians in a 'great bloodbath that was so common amongst Greeks' (Hdt. 7.170.3). Aristotle offers the terse comment: 'In Tarentum, following the defeat in which many eminent citizens were killed by the Iapyges (= Messapians) not long after the Persian wars, a democracy replaced the government' (Aristotle Politics 1303a3-5).

Enduring internal disputes within the poleis and constant rivalries amongst the poleis are characteristic features of conditions in both Sicily and southern Italy. On the other hand, in southern Italy conflicts with the indigenous population became accentuated in the course of the fifth century, while in Sicily Syracuse succeeded in thwarting Sicel ambitions. The cities of southern Italy came increasingly under the pressure of native tribes who - as already noted - united together in strong alliances and thereby presented great potential for aggression. In order to confront this threat, the Greek cities came closer together. In the last third of the fifth century at the latest, the cities of Kroton, Kaulonia and Sybaris (re-founded after civil strife had erupted in Thourioi by citizens who consequently chose to leave their city) formed the -nucleus of an alliance that was modelled on the institutional structures of the federal principles of the Achaian League in the Peloponnese (Polybios 2.39.4-6). This league not only became effective in terms of foreign policy, but may at the same time also have contributed decisively to stabilizing democratic constitutions in the member states of the league.

\section{The Return of the Past? The Fourth Century}

\section{A kingdom of two Sicilies}

The experiences of the military conflicts of the last three decades of the fifth century must have come as a shock to the Syracusans. Thanks to military skill and also to luck and chance, they had succeeded within a short time in extricating themselves from the imperial advances of two major states. For neither Athens nor Carthage was it any longer merely a question of lending support to their Sicilian allies. The pleas for help from Leontinoi $(427)$ and Segesta $(416 / 15)$ were for Athens little more than a pretext for their attempt to extend their supremacy also to the West (Thuc. 6.6.1). And when in 409 the Carthaginians - so to speak in the aftermath of the Athenian defeat - took up Segesta's cause, and after 70 years of peaceful restraint carried on war in Sicily, there could no longer be any doubt, in the face of the escalation of the conflict, that in the final analysis what was at issue was hegemony and no longer the protection of an Elymian city. The mighty military hardware which in 415 - after the prelude of 427 - Athens threw into action and the devastating consequences of 
Carthage's military campaigns since 409 , which culminated in the massacre of 3,000 Greeks in Himera - as revenge for $\mathbf{4 8 0}$ - and in the destruction of Akragas, made the Syracusans all too aware of the threat to their very existence. The resultant prevailing mood may have been a decisive factor in preparing the way, in the confusion of the most intense internal disputes, for Dionysios to be acclaimed strategos autokrator. (i.e., chief commander with plenipotentiary powers) in 405 .

This office, which in the Syracusan constitution was designed to come into effect in political crises, Dionysios used to establish his personal power base and organized it into the 'greatest and longest tyranny in history' (Diodoros 13.96.4). It is undeniable that here Gelon and Hieron were his models, for he employed the same tools for governing, except that he wielded them with far greater rigour and severity, and on a much greater scale - in accordance with his unquestionably greater ambitions. A mercenary army, drawn from virtually all parts of the Mediterranean, but especially from the Peloponnese and central and northern Italy, constituted the foundation of his power. These mercenaries served Dionysios not only in the capacity of fighting troops, but also as a bodyguard, as occupation troops in conquered cities and, after disarmament of the Syracusan citizenry, as a substitute for militiamen. Syracuse, celebrated already by Pindar as a Megale Polis (Pindar Pythian Odes 2.1), was provided with gigantic fortifications and turned into the largest city in the Greek world. Thanks to a defence industry of the most modern type, it resembled a massive munitions factory (Diodoros 14.18.2-8; 41.3-43.4).

After Dionysios had relinquished almost half of Sicily to the Carthaginians in the peace treaty of 405 , and, in addition, granted autonomy to other parts of the island, and at least secured Carthaginian recognition to implement his rule over Syracuse (Diodoros 13.114.1), he took decisive action against the cities of Sicily in the following years. By means of large-scale forced settlements and by giving citizen rights to soldiers and former slaves, Dionysios succeeded step by step in breaking down the resistance of the cities and in bringing them under his control. He did not, however, confine himself to Sicily, but, in an alliance with Lokroi - even more decisively than Hieron had in his day - also crossed over to Italy. As a result, the Greek cities in southern Italy found themselves caught between two fronts: they had to defend themselves, on the one hand, against the increasingly aggressive attacks of the local tribes of the Lucanians and Samnites, and, on the other, against the attacks of Dionysios. In this situation, at the beginning of the fourth century, Thourioi, Hipponion, Rhegion, Elea and perhaps Naples, along with other cities, joined the existing League composed of Kroton, Sybaris and Kaulonia, and formed the Italiote league. With his victory at the Eleporos river in 388 , however, Dionysios put a quick end to this league. The Syracusan territory stretched as far as the Isthmus of Catanzaro, and with the seizure of Rhegion (386) Syracuse ultimately gained control of the straits between Sicily and Italy, especially also after the destruction of Hipponion and Kaulonia and the deportation of their inhabitants to Syracuse, put an end to her most determined adversaries. The toe of Italy, however, served Dionysios merely as a bridgehead for much more ambitious plans. An alliance with the Lucanians as well as a reorganization of the Italiote League, the leadership of which passed to Tarentum, expanded the Syracusan sphere of influence over many parts of southern Italy. And with the founding of Ankon (Ancona), Hatria, Issa and possibly Lissos, Dionysios extended his net of colonies across the Adriatic. Attempts by the 
Carthaginians to set foot in southern Italy, however, in the end came to nothing, whereas in Sicily they had a number of successes, and finally secured their epikrateia in a line running from Himera to Herakleia Minoa (Diodoros 15.17.5).

What could still be construed as liberation of the Greeks from the yoke of barbarism in the war against the Carthaginians between 398 and 392 (Diodoros 14.46.5) soon came up against a fundamental contradiction in the Greek world: e.g., in a passionate speech by the Athenian Lysias (Lysias 33) in 388, during the Olympian games, containing his call to arms against both suppressers of Greek freedom, the Great King and the 'tyrants of Sicily'; and Isokrates' complaint in 380: 'Italy has been devastated, Sicily enslaved' (Isokrates 4.169). Dionysios, however, trumped all his critics in the power game, and succeeded in working his way even into the politics of the motherland - at first on the side of Sparta, and then also as a friend (and citizen) of Athens (R\&O 33; 34). And until his death he held an empire together 'in iron chains' (Diodoros 16.5.4; Plutarch Dionysios 7.6) which, at least in terms of its geographical dimensions, but perhaps also in respect of its political aims, came close to what in 1815 was singled out from the remains of the Napoleonic empire as the 'Kingdom of the Two Sicilies'.

\section{Futile new beginnings}

Things seemed to repeat themselves in Syracuse. As scarcely a hundred years earlier, so once again the successors were incapable of maintaining the inheritance of their predecessors. Dionysios I had scarcely died in 367 when the 'iron chains' snapped with which he had held the kingdom he had created together. The tyranny of his son and successor Dionysios II was doomed to failure, since his father had kept him well clear of state affairs. He was unfortunate in his foreign policy, and became the helpless victim in the growing Court intrigues and power conflicts, in which Dion, both brother-in-law and son-in-law of Dionysios I, played a leading role. Dion, a friend of the philosopher Plato, saw in the change of throne from father to son an opportune occasion, under the influence of Platonic ideas, to put into practice his own political theories in Syracuse. In the face of the political realities, however, the experiment ended in a lamentable failure, despite several attempts. Nor did the fact that Plato was present in person, twice summoned to the Court of the tyrant (366 and 361), make any difference. On the instigation of his opponents, who included the historian Philistos, Dion was forced to flee into exile to Greece in 366. In 357, however, he returned to Syracuse with a small mercenary force, and after fluctuating battles succeeded in overthrowing Dionysios II, and forced him to flee into exile in Lokroi. But Dion's renewed attempt to carry out a radical change in the constitution of Syracuse met with growing opposition, and led to his assassination in 354 , by his most intimate confidants.

With Dion's death Syracuse was plunged into anarchy. In quick succession a number of individuals took over as tyrants: first Dion's assassin Kallippos, then two half-brothers of Dionysios II, namely Hipparinos (in 353) and Nysaios (in 351), and finally Dionysios II once more himself (in 347). This disintegration of political power was not without its effect on foreign policy. The 'Kingdom of the Two Sicilies' collapsed and revealed the same lack of unity as in the Greek motherland, where in the words of Xenophon, 'chaos and discord were greater than ever before' 
(Xenophon Hellenika 7.5.27). In southern Italy the Bruttians broke away from the Lucanians, and expanded their power over former Syracusan territory at the tip of south-west Italy. Thanks to the fact that Syracuse had become powerless, the Italiotes had lost rear cover, and so had to defend themselves all the more against attacks from their local neighbours. On Sicily, virtually all cities had broken away from Syracuse and were under the rule of local tyrants, who with the support of mercenary alliances carried on war against each other. In addition, 'the Carthaginians turned up on the shores of Sicily with a huge fleet and, hovering over the Greeks of the island, posed a permanent threat' (Plutarch Timoleon 2.1).

In this situation the Syracusans followed a time-worn pattern: they sought help from without. As so often in the past, they turned to their mother-city, Korinth, which in $\mathbf{3 4 5}$ sent Timoleon as a mediator. His mission was to lead Sicily once more to a new period of power. The 'revival of Sicily' (Talbert 1974) associated with Timoleon's name no doubt belongs to one of the most astonishing moments in Greek history in the Classical period. In less than a decade he not only restored the old frontiers of Syracuse's epikrateia, but also liberated Syracuse and all the other cities of Sicily from tyranny. Syracuse became the centre of a league of free cities, whose political and economic base Timoleon completely overhauled. He pursued a very deliberate policy of reviving the urban diversity of Sicily, and thereby counterchecked the policies of the Syracusan tyrants. For the resettlement of Syracuse alone he is said to have drawn 60,000 new colonists from Greece, Italy and Sicily (Plutarch Timoleon 23.6), but all the other cities also experienced a new period of flowering. The accounts of ancient authors, however, reflect only the beginnings of the extent of this restoration policy, and it is not until we turn to the numismatic and above all the archaeological evidence that we get a clearer picture of the enormous dimensions it assumed. This also explains why Timoleon upon his death was buried as an oikistes, the founder of a colony, in the market place in Syracuse and why annual games were decreed in his honour, 'because he overthrew the tyranny, conquered the barbarians, rebuilt the largest of the cities which had been destroyed and restored to the Siceliots their freedom' (Plutarch Timoleon 39.4).

This freedom did not, however, last very long. Soon after Timoleon's death Sicily as earlier also the rest of the West - was plunged into fresh political chaos, which was once more finally to lead back to tyrannis. Plato's warning, which he published already in his eighth Letter $(8.353 \mathrm{D}-\mathrm{E})$, was to be valid for a long time:

but what seems to be the end of the old is always being linked on to the beginning of a new brood; and because of this endless chain of evil the whole tribe of tyrants and democrats alike will be in danger of destruction. But should any of these consequences ... come to pass, hardly a trace of the Greek tongue will remain in all Sicily, since it will have been transformed into a province or dependency of Phoenicians or Oscans.

\section{Further reading}

An excellent survey of the state of research can be found in the regularly published Acts of the Convegni di studi sulla Magna Grecia (organized annually since 1961), as well as 
in the Acts of the Congressi internazionali di studi sulla Sicilia antica, which are published in the journal Kokalos. The results of archaeological research are published regularly in Archaeological Reports - the latest by de Angelis (2001) and Ridgway (2002). The Bibliography to follow here is confined almost exclusively to studies in English, but it must be emphasized that for any detailed investigation in the history of the Greek West research published in Italian is mandatory. Additional literature can readily be found in the bibliographies in the studies cited below.

\section{Bibliography}

Asheri, D. (1988) 'Carthaginians and Greeks' in: $C A H^{2} 4739-80$

Asheri, D. (1992) 'Sicily, 478-431 B.C.' in: $C A H^{2} 5$ 147-70

Berger, S. (1992) Revolution and society in Greek Sicily and southern Italy (Stuttgart: Steiner) (Historia Einzelschriften 71)

Caven, B. (1990) Dionysius I: par-lord of Sicily (New Haven: Yale University Press)

Cerchiai, L., L. Jannelli, F. Longo (2004) The Greek cities of Magna Graecia and Sicily (Los Angeles: J. Paul Getty Museum)

De Angelis, F. (2001) 'Archaeology in Sicily 1996-2000' in: Archaeological Reports 47: 145201

De Angelis, F. (2003) Megara Hyblaia and Selinous: the development of two Greek city-states in archaic Sicily (Oxford: Oxford University School of Archaeology) (Oxford University School of Archaeology Monograph 57)

Dunbabin, T. J. (1948) The western Greeks: the history of Sicily and south Italy from the foundations of the Greek colonies to 480 B.C. (Oxford: Clarendon)

Finley, M. I. (1979) Ancient Sicily (revised edition) (London: Chatto \& Windus 1979)

Gabba, E., \& G. Vallet (eds) (1980) La Sicilia antica, vol. 2, part 1: La Sicilia greca dal sesto secolo alle guerre puniche (Palermo: Lombardi)

Hall, J. (2004) 'How "Greek" were the early western Greeks?' in: Lomas, K. (ed.) (2004) Greek identity in the western Mediterranean: papers in honour of Brian Shefton (Leiden: Brill) 35-54 (Mnemosyne Suppl. 246)

Jameson, M. H., D. R. Jordan, R. D. Kotansky (1993) A 'lex sacra' from Selinous (Durham NC: Duke University Press)

Kirsten, E. (1975) Suditalienkunde: Ein Führer zu klassischen Stätten, vol. 1: Campanien und seine Nachbarlandschaften (Heidelberg: Winter)

Lewis, D. M. (1994) 'Sicily, 413-368 в.C.' in: $\mathrm{CAH}^{2} 6$ 120-55

Lomas, K. (2000) 'The polis in Italy: ethnicity and citizenship in the western Mediterranean' in: Brock, R, \& S. Hodkinson (eds) (2000) 'Alternatives to Athens: varieties of political organization and community in ancient Greece (Oxford: Oxford University Press) 167-85

Pugliese Carratelli, G. (ed.) (1996) The western Greeks: classical civilization in the western Mediterranean (London: Thames \& Hudson)

Purcell, N. (1994) 'South Italy in the fourth century' in: $C A H^{2} 6381-403$

Ridgway, D. (2002) 'Archaeology in Sardinia and south Italy 1995-2001' in: Archaeological Reports 48: 117-38

Rutter, N. K. (1997) The Greek coinages of southern Italy and Sicily (London: Spink)

Sjöqvist, E. (1978) Sicily and the Greeks: studies in the interrelationship between the indigenous populations and the Greek colonists (Ann Arbor: University of Michigan Press) (Jerome Lectures 9) 
Smarczyk, B. (2003) Timoleon und die Neugründung von Syrakus (Göttingen: Vandenhoeck \& Ruprecht) (Abhandlungen der Akademie der Wissenschaften zu Göttingen, Philologischhistorische Klasse 3, 251)

Smith, C. J., \& J. Serrati (eds) (2000) Sicily from Aeneas to Augustus: new approaches in archaeology and bistory (Edinburgh: Edinburgh University Press) (New Perspectives on the Ancient World 1)

Talbert, R. J. A. (1974) Timoleon and the revival of Greek Sicily, 344-317 B.C. (London: Cambridge University Press) (Cambridge Classical Studies)

Talbert, R. J. A. (1997) 'The Greeks in Sicily and south Italy' in: Tritle, L. A. (ed.) (1997) The Greek world in the fourth century: from the fall of the Athenian empire to the successors of Alexander (London: Routledge) 137-65

Walbank, F. W. (1968-9) 'The historians of Greek Sicily' in: Kokalos. 14-15: 476-98

Westlake, H. D. (1994) 'Dion and Timoleon' in: $C A H^{2} 6$ 693-722 